\title{
Quality Of Duck Eggs At Different Soaking Times In Noni Leaf Extract Stored For 15 Days
}

\author{
Sri Sukaryani ${ }^{1}$, Engkus Ainul Yakin ${ }^{2}$ and Hardika Eka Rhamadanu ${ }^{3}$ \\ ${ }^{12,3}$ Animal Husbandry Study Program, Faculty of Agriculture, University of Veterans \\ Bangun Nusantara, Sukoharjo, Indonesia \\ Corresponding author : srisukaryani@gmail.com
}

\begin{abstract}
Duck eggs were one type of protein source food that was much favored by the people of Indonesia. However, currently there are not many ways of preservation to maintain the quality of duck eggs in storage. With preservation by immersion with noni leaf extract, it can be an alternative in maintaining the quality of duck eggs in storage for 15 days. This was because noni leaves contain elements of chemical compounds such as amino acids, phenolic compounds, ursulic acid, alkaloids, phenols, and glycosides which are antimicrobial, antibacterial and anti-inflammatory. This study aims to determine the effect of soaking duck eggs in noni leaf extract on the interior quality of duck eggs. This study used a completely randomized design (CRD) with a concentration of $45 \%$ noni leaf extract with immersion time of $0,12,24,36$ and 48 hours with 3 replications. To determine whether there is a difference in treatment using Duncan Multiple Range Test $(\mathrm{DMRT})$ at the level of $=0.05$. The research variables are albumen index, yolk index and haugh unit. Data were analyzed by SPSS. The results of the study concluded that soaking duck eggs with noni leaf extract for 12-48 hours with an extract concentration of $45 \%$ had no significant effect on egg quality in this case the yolk index, albumen index and haugh unit.
\end{abstract}

Keywords: duck egg, noni leaf extract, duck egg quality

\section{Introduction}

Indonesian duck egg production experienced ups and downs from 2018 to 2020, in 2018 it was 338507.58 tons to 328686.53 tons in 2019 and in 2020 duck egg production in Indonesia was 332907.32 tons. The fluctuation in the number of duck egg production shows that the use and consumption of domestic duck eggs by the public and the food industry (including the pharmaceutical and herbal medicine industries) fluctuates. The production and quality of duck eggs is strongly influenced by the rearing system carried out by breeders (Ditjenak \& Keswan, 2020).

Eggs contain fat-soluble vitamins (A, D, E, and K), and also water-soluble vitamins (thiamin, riboflavin, pantothenic acid, niacin, folic acid, and vitamin B12). Egg yolks are quite high in cholesterol content (Miranda et al., 2015). Eggs have properties that are easily damaged, both physical damage and damage due to microorganism attacks through the pores of the egg shell. The physical properties of eggs that are easily damaged cause the need for handling methods so that the eggs have a long enough shelf life (Lukito, 2012).

Efforts to extend the shelf life of eggs so that they can last a long time are done by means of preservation. Preservation used is natural preservation, and safe if consumed 
(Rahmawati et al., 2014). Preservation technology is needed in order to maintain egg quality for a long time. Several researchers have reported on preservation technology, including Faikoh (2014) stating that one of the methods of preserving eggs is by using vegetable tanning. Furthermore, Faikoh (2014) states that the basic principle of preservation using vegetable tanners is the occurrence of a tanning reaction on the outside of the egg shell by a tanning agent. One of the known tanning substances is tannin.

Noni leaves (Morinda citrifolia) contain anthraquinones (such as nordamnacanthal, morindone, rubiadin, rubiadin-1-methyl ether, anthraquinone glycoside) (Aruna, 2013) which can suppress the growth of Pseudomonas aeruginosa, Proteus morganii, Staphylococus aureus, Bacillus subtilis, and E.coli (Kameswari, 2013), so it can be used as a natural preservative. In addition to anthraquinones, Wardiny et al explained that noni leaves contain other ingredients such as amino acids, phenolic compounds, ursulic acid, alkaloids, phenols, and glycosides which are antimicrobial, antibacterial and anti-inflammatory (Wardiny et al., 2012). So there is a need for a study to determine the effect of soaking eggs in noni leaf extract on the quality of duck eggs.

\section{Materials and Methods}

\section{Research Location and Time}

This research was carried out on June 7, 2021 to June 22, 2021. At the Laboratory of the Faculty of Agriculture, University Veteran Bangun Nusantara Sukoharjo.

\section{Research Material}

The materials used are duck eggs, noni leaves and aquades. While the tools used are analytical scales, caliper, deep micrometer and glass plate. This study uses experimental research methods. Making noni leaf extract by means of cutting the noni leaves into small pieces then boiling the distilled water until it boils then add the noni leaves that have been cut into small pieces, wait about 10-15 minutes then remove and filter the noni leaf extract. Then prepare the duck eggs that have been cleaned using a wet cloth and then carry out the process of soaking the duck eggs with a concentration of $45 \%$ noni leaf extract. Treatment P0 eggs without soaking as a control, P1 soaked with noni leaf extract for 12 hours, P2 soaked with noni leaf extract for 24 hours, P3 soaked with noni leaf extract for 36 hours and P4 soaked with noni leaf extract for 48 hours. After the immersion time is complete, remove the eggs and drain and place them in the egg tray and then store them at room temperature for 15 days.

\section{Experimental Design}

This study used a completely randomized design (CRD) with a unidirectional pattern with 5 kinds of treatment and each replication was repeated 3 times.

The treatment is as follows:

P0: Duck eggs without soaking in noni leaf extract

P1: Duck eggs soaked in noni leaf extract with a concentration of $45 \%$ for 12 hours 
P2: Duck eggs soaked in noni leaf extract with a concentration of $45 \%$ for 24 hours

P3: Duck eggs soaked in noni leaf extract with a concentration of $45 \%$ for 36 hours

P4: Duck eggs soaked in noni leaf extract with a concentration of $45 \%$ for 48 hours

After the soaking time is reached, then the eggs are drained and stored at room temperature for 15 days.

\section{Observed Variables}

The next process is checking the quality of duck eggs by calculating the diameter of the yolk and egg white. The variables observed are albumen index, yolk index and Haugh index.

Albumen Index, can be calculated using the formula Andi (2013) as follows:

$$
\text { albumen indeks }=\frac{\text { tinggi albumen }(\mathrm{mm})}{\text { diameter albumen }(\mathrm{mm})}
$$

Yolk Index, can be calculated using the formula Andi (2013) as follows:

$$
\text { yolk indeks }=\frac{\text { tinggi yolk }(\mathrm{mm})}{\text { diameter yolk }(\mathrm{mm})}
$$

Haugh Unit, calculated using the following formula Andi (2013) :

$\mathrm{HU}=100 \operatorname{logs}(\mathrm{H}+7.57-1.7 \mathrm{~W} 0.37)$

Information:

$\mathrm{HU}=$ haught units

$\mathrm{H}=$ egg albumin height

$\mathrm{W}=$ egg weight (grams)

\section{Data Analysis}

The data that has been collected is then analyzed statistically using analysis of variance, if there is a difference, a further test will be carried out using the Duncan't Multiple Range Test (DMRT) (Mulyono, 2011)

\section{Results and Discussion}

\section{Albumin Index}

Egg albumen index is the ratio of thick egg albumen height to egg white width. The egg white is the part of a whole egg which makes up about 58-60\% of the egg's weight and has two layers, namely a thick layer and a thin layer. The complete data of the average albumen index value of the research results are listed in table 1.

Table 1. The Average Albumen Index Value Of Eggs With Noni Leaf Extract Soaking

\begin{tabular}{cccccc}
\hline \multirow{2}{*}{ Replication } & \multicolumn{5}{c}{ Treatment } \\
\cline { 2 - 6 } & P0 & P1 & P2 & P3 & P4 \\
\hline 1 & 0.03 & 0.03 & 0.02 & 0.03 & 0.03 \\
2 & 0.03 & 0.03 & 0.03 & 0.02 & 0.03 \\
3 & 0.05 & 0.04 & 0.04 & 0.03 & 0.05 \\
\hline Average $^{\text {ns }}$ & 0.036 & 0.033 & 0.030 & 0.026 & 0.036 \\
\hline
\end{tabular}

$\mathrm{ns}=$ description is not real $(\mathrm{P}>0.05)$ 
Table 1 after statistical testing showed that $45 \%$ noni leaf extract used to soak duck eggs for 12-48 hours had no significant effect on albumen index $(\mathrm{P}>0.05)$. It can be said that duck eggs stored for 15 days at room temperature treated with noni leaf extract or not, the albumen index value was the same. This shows that noni leaf extract containing tannin can inhibit the process of evaporation of egg contents because the pores of duck eggs are covered by tannin.

Sulistina et al. (2017) stated that the change in the egg white index occurred due to the ovomucin bond in the egg white structure undergoing a transformation due to the opening of the egg shell pores, this indicates that the tannin content in green tea cannot maintain the quality of the egg white index.

Treatment of P4 albumen index value tended not to decrease albumen value. It is suspected that the longer soaking with noni leaf extract can maintain egg quality. This is because the tannins in the noni leaf solution contain ursolic acid (Rukmana, 2002). Tannins can be used as an egg preservative for a long time, which is about 4 weeks (Sukardi et al, 2007).

\section{Yolk Index}

The results of analysis of variance showed that soaking eggs in noni leaf extract for 12-48 hours with a concentration of $45 \%$ had no significant effect on egg yolk index. Table 2 shows that the average value of egg yolk index P0 is $0.316, \mathrm{P} 1$ is 0.356 ; $\mathrm{P} 2$ is $0.373, \mathrm{P} 3$ is 0.330 and $\mathrm{P} 4$ is 0.343 .

Table 2. The Average Yolk Index Value Of Eggs With Noni Leaf Extract Soaking

\begin{tabular}{cccccc}
\hline \multirow{2}{*}{ Replication } & \multicolumn{5}{c}{ Treatment } \\
\cline { 2 - 6 } & P0 & P1 & P2 & P3 & P4 \\
\hline 1 & 0.35 & 0.32 & 0.35 & 0.32 & 0.33 \\
2 & 0.25 & 0.33 & 0.35 & 0.34 & 0.34 \\
3 & 0.35 & 0.42 & 0.42 & 0.33 & 0.36 \\
\hline Average $^{\text {ns }}$ & 0.316 & 0.356 & 0.373 & 0.330 & 0.343 \\
\hline ns = non significant $(\mathrm{P}>0.05)$ &
\end{tabular}

The above is in accordance with the research of Sulistina et al. (2017) which used green tea solution showed that the average egg yolk index decreased at a concentration of $30 \%$ having a value of 0.21 when soaking green tea solution for 36 hours with storage for 2 weeks gave no significantly different results $(\mathrm{P}>0.05)$. In general, the yolk index value of eggs decreased with the length of storage. This shows a decrease in the vitelline membrane and watery yolk, which is mostly caused by the diffusion of water from the egg albumen.

According to SNI 3926:2008, the egg yolk index with quality I must be 0.458 0.521 , quality II of $0.394-0.457$, and quality III of $0.330-0.393$. It can be seen from the SNI standard, the egg yolk index at P1, P2, P3 and P4 is still in the SNI standard range, so the egg is still fit for consumption. In contrast to eggs that were not soaked at $\mathrm{P} 0$, at 15 days of storage they tended to start to spoil. Egg yolk index was influenced by storage time, increase in $\mathrm{pH}$ due to $\mathrm{CO}_{2}$ evaporation and damage to ovomucin fibers. 
The longer it is stored, the lower the index value of the egg yolk will be because the osmotic pressure on the yolk is greater than that of the egg white, so that water and egg white move to the yolk. Continuous movement of water will cause the size of the yolk to decrease which causes the yolk to become flat and then break, the displacement of water depends on the thickness of the egg white (Pando et al., 2012).

The difference in osmotic pressure due to the process of water evaporation from the continuous flow of water from the egg white to the yolk through the vitelline process causes a decrease in the elasticity of the vitelline membrane with the enlargement of the yolk. The strength of the vitellin membrane decreases with increasing age of the egg, the vitellin membrane becomes weaker and more elastic and some of its components change or disappear. This is because some microorganisms that enter through the egg white produce proteolytic enzymes that cause the vitamin membrane to become weaker (Keener et al., 2006).

\section{Haugh Index}

The results of the analysis of variance from table 3 show that soaking duck eggs in noni leaf extract for 12-48 hours with an extract concentration of $45 \%$ had no significant effect on the egg Haugh index value (P>0.05). Based on Table 3, P1 gives the haugh index value of 53.86, P2 is $48.10, \mathrm{P} 3$ is 39.66 and $\mathrm{P} 4$ is 53.02 while $\mathrm{P} 0$ gives a value of 54.11 .

Table 3. The Average Haugh Index Value Of Eggs With Noni Leaf Extract Soaking

\begin{tabular}{cccccc}
\hline \multirow{2}{*}{ Replication } & \multicolumn{5}{c}{ Treatment } \\
\cline { 2 - 6 } & P0 & P1 & P2 & P3 & P4 \\
\hline 1 & 47.60 & 51.93 & 26.82 & 50.04 & 51.76 \\
2 & 54.05 & 46.97 & 56.29 & 19.59 & 49.91 \\
3 & 60.68 & 62.69 & 61.20 & 49.36 & 57.39 \\
\hline Average $^{\text {ns }}$ & 54.11 & 53.86 & 48.10 & 39.66 & 53.02 \\
\hline ns = non significant $(\mathrm{P}>0.05)$
\end{tabular}

The ratio of the height and weight of the measured eggs is given a rating of 20100 or more. According to SNI 01-3926-2006, the freshness of eggs is distinguished by: a) Quality I, having a HU value $>72$. b) Quality II, has a HU value of 62-72. c) Quality III, has a HU value $<60$. Of the five treatments, the haugh index value is in quality III has a HU value $<60$.

The longer the storage, the lower the egg quality caused by the evaporation of $\mathrm{CO}_{2}$ through the egg pores. The higher the ovomucin content in the egg white, the higher the HU value. If there is less ovomucin in the egg white, the egg white will melt faster. Ovomucin is useful as a structure-forming egg white (Stadelman et al., 1997)

Research conducted by Sulistina et al. (2017), using a green tea solution showed the average Haugh unit at a concentration of $30 \%$ gave a value of 37.80 with immersion for 36 hours and storage for 2 weeks at room temperature gave no significant difference $(\mathrm{P}>0.05)$. The more dilute the egg albumen, the smaller the HU value so the lower the egg quality. The thickness of the egg white is related to the content of ovomucin in the 
egg albumen. Watery egg whites are caused by damage that occurs to ovomucin so that water will come out of the egg protein.

\section{Conclusion}

Based on the results of the study, it can be concluded that soaking duck eggs with noni leaf extract for 12-48 hours with an extract concentration of $45 \%$ did not significantly affect egg quality in this case the yolk index, albumen index and Haugh index.

\section{References}

Andi, N. M. 2013. Effect of Melinjo Leaf Extract Level (Gnetum gnemon Linn) and Different Storage Time on Egg Quality. Thesis. Hasanuddin University. Makasar.

Aruna M, Santhosh et al. 2013. Ashuka: A Hub Of Medicinal Values. International Journal of Biological \& Pharmaceutical Research. Vol : 4 (12). Pages : 10431049.

Ditjenak \& Keswan. 2020. Book of Livestock Statistics. Directorate General of Livestock and Animal Health. Ministry of Agriculture of the Republic of Indonesia.

Faikoh, N.E. 2014. The Miracle of Eggs. Media Palace, Yogyakarta.

Kameswari, Made Sumitha, I Nengah Kerta Besung and Hapsari Mahatmi. 2013. Extract of Noni (Morinda citrifolia) Leaves Inhibits the Growth of Escherichia coli Bacteria In Vitro. Faculty of Veterinary Medicine, Udayana University. 2(2) : $216-224$.

Keener, K. M., K. C. McAvoy, J. B. Foegeding, P. A. Curtis, K. E. Anderson. J. Osborne. 2006. Effect of testing temperature on internal egg quality measurements. Poultry Science. 85:550 - 555.

Lukito, G. A. 2012. The Effect of Various Salting Methods on NaCl Levels, Elasticity and Consumer Preference Levels on Salted Quail Eggs. Journal of Animal Agriculture. 1 (1): 829-838.

Miranda JM, Anton X, Valbuena CR, Saavedra PR, Rodriguez JA, Lamas A, Franco CM, Cepeda A. 2015. Egg and egg-derived foods. J Nutrients, 7:706-729.

Mulyono A.M.W. 2011. Experimental design. Animal Production Study Program, Faculty of Agriculture. University of Bantara Sukoharjo. Sukoharjo.

Pando, S., L. Thomsen, A. Balen. 2012. Physical transport properties of marine microplastic polution. Biogeosci 9:18755 - 18798.

Rahmawati, S., T. R. Setyawati and A. H. Yanti. 2014. Shelf Life and Quality of Chicken Eggs Coated with Coconut Oil, Betel Lime and Ethanol Extract of Rosella Petals. Protobiont 1(3): 55-60. 
Rukmana. 2002. Shallots: Cultivation and Postharvest Management. Yogyakarta: Kanisius

Stadelman, W. J. and O. J. Cotterill. 1997. Egg Science and Technology. 4th Edition. Food Products Press. An Imprint of the Haworth Press, Inc., New York.

Sukardi, A. R., Mulyarto and W. Safera. 2007. Optimization of extraction time on the tannin content of guava leaf extract powder and production costs. J. Agricultural Technology Vol. 2(8): 88-94.

Sulistina L. Imanudin O. and Falahudin A. 2017. Effect of Soaking Green Tea (Camellia Sinensis) Extract on Interior Quality of Chicken Eggs. Faculty of Animal Husbandry, Majalengka University, Bandung

Wardiny, T.M. 2012. The Effect of Noni Leaf Extract on the Blood Profile of Starter Quail. JITP. Vol: 2. No: 2. 